Article

\title{
Low Family Support and Risk of Obesity among Black Youth: Role of Gender and Ethnicity
}

\author{
Shervin Assari 1,2,* and Cleopatra Howard Caldwell ${ }^{2,3}$ \\ 1 Department of Psychiatry, School of Medicine, University of Michigan, Ann Arbor, MI 48109, USA \\ 2 Center for Research on Ethnicity, Culture and Health, School of Public Health, University of Michigan, \\ Ann Arbor, MI 48109-2029, USA; cleoc@umich.edu \\ 3 Department of Health Behavior and Health Education, School of Public Health, University of Michigan, \\ Ann Arbor, MI 48109-2029, USA \\ * Correspondence: assari@umich.edu; Tel.: +1-734-858-8333; Fax: +1-734-763-7379
}

Academic Editor: Sari A. Acra

Received: 21 February 2017; Accepted: 20 April 2017; Published: 12 May 2017

\begin{abstract}
Most studies on the role of family environment in developing risk of obesity among youth have focused on parenting behaviors that are directly involved in energy balance in regional, non-representative White samples. Using a national sample of ethnically diverse Black youth, the current study tested the association between low family support and risk of obesity. We also tested the heterogeneity of this association based on gender, ethnicity, and their intersection. We used data from the National Survey of American Life-Adolescent Supplement (NSAL-A), a national survey of Black adolescents in the United States. The study enrolled 1170 African American and Caribbean Black 13-17 year old youth. Obesity was defined based on the cutoff points of body mass index (BMI) appropriate for age and gender of youth. Family support was measured using a five-item measure that captured emotional and tangible social support. Age, gender, and ethnicity were also measured. Logistic regressions were utilized in the pooled sample, and also based on gender, ethnicity, and their intersection, to test the link between low family support and risk for obesity. Results: In the pooled sample, low family support was not associated with an increased risk of obesity (OR $=1.35,95 \%$ Confidence Interval $(\mathrm{CI})=0.96-1.89$ ). The association between low family support and risk of obesity was, however, significant among African American females ( $\mathrm{OR}=1.60,95 \% \mathrm{CI}=1.01-2.55)$. There was no association for African American males $(\mathrm{OR}=1.26,95 \% \mathrm{CI}=0.82-1.92)$, Caribbean Black males $(\mathrm{OR}=0.68,95 \% \mathrm{CI}=0.01-54.85)$, and Caribbean Black females $(\mathrm{OR}=0.78,95 \% \mathrm{CI}=0.42-1.44)$. In conclusion, policies and programs that enable African American families to provide additional family support may prevent obesity among African American female youth. Future research should test the efficacy of promoting family support as a tool for preventing obesity among African American female youth.
\end{abstract}

Keywords: African Americans; youth; gender; ethnicity; parenting; family support; social support

\section{Background}

Family influences on risk of obesity among offspring are well established [1-6]. The majority of this evidence, however, is based on studies with local, non-representative, and mostly White samples $[3,4,7]$. Available research has mostly focused on family processes that are directly involved in energy balance, such as food consumption, physical activity, and sedentary life style issues [3-13]. As a result, less is known about the role of more general family processes such as family support, particularly among minority youth [2].

While family can be a part of the obesogenic environment for youth [14], it is unknown whether attributes that reflect overall family functioning (such as low family support) - but are not directly 
related to energy balance-also increase risk of obesity of the offspring. It is also still unknown whether such effects exist for Black youth $[15,16]$. Further, less information is available regarding whether the salience of low family support as a risk factor for obesity is universal across gender and ethnic groups [2]. Given the limits of existing knowledge, there is a need to develop a rich understanding of how ethnicity, gender, and their intersection alter the role of family environment on risk of obesity in Black youth [2].

Research has shown that race, ethnicity, gender, and their intersections alter psychosocial determinants of obesity [17-33]. Ethnic groups, for example, differ in the salience of psychosocial factors on obesity [29]. Gender also alters the relevance of family support for obesity [2]. The intersection of ethnicity and gender also alters psychosocial correlates of obesity $[17,23,24]$. In a recent study by Assari et al., 227 African American youth (109 male and 118 female) were followed for 12 years from age 20 to age 32. The study showed that among females, but not males, low maternal support during adolescence was a risk factor for an increase in body mass index (BMI) a decade later when they were young adults [2].

Researchers have found that the family environment affects behaviors that influence feeding, exercise, nutrition, and sedentary life style [15,34-41]; yet the existing knowledge regarding the obesity risk attributable to low sense of family closeness, support, and warmth is limited [35-38]. Although abuse, neglect, and harsh parenting (which operate as stressors) may increase risk of obesity [39,40], less is known about potential effects of poor family support on risk of obesity. While lack of emotional support may increase risk of obesity particularly for youth who live in a disadvantaged environment and deal with stress on a daily basis, the mechanism of the effects of such general family attributes is not directly through altering energy balance [2,41].

Using a national sample, the current study investigated the association between low family support and risk of obesity among ethnically diverse Black youth. We also tested possible heterogeneity of this association based on ethnicity, gender, and their intersection in an effort to understand more nuances about subgroup differences in Black youth. We hypothesized that low family support would be associated with higher odds of obesity in the pooled sample of Black youth. We also hypothesized ethnic by gender variation in this association, with a more salient role of low family support as a risk factor for obesity for African American females. Although we are not aware of any previous studies on ethnic by gender variation of this association among Black youth, low family support is shown to influence the risk factor for obesity in African American females [2].

\section{Materials and Methods}

\subsection{Design and Setting}

This was a cross-sectional study using data from the National Survey of American Life-Adolescent Supplement (NSAL-A) 2003 [42-45]. Funded by the National Institute of Mental Health (NIMH) and included in the Collaborative Psychiatric Epidemiology Surveys (CPES), the NSAL-A is a part of the National Survey of American Life (NSAL). The NSAL-A is one of the largest and most updated mental health surveys of Black youth ever conducted in the United States $[44,45]$.

The NSAL-A received approval from the Institutional Review Board (IRB), University of Michigan, Ann Arbor. Informed consent was obtained from youth's legal guardians. Assent was obtained from youth themselves. All respondents received monetary compensation $(\$ 50)$ for their participation.

\subsection{Participants}

\subsubsection{NSAL Sample}

The NSAL, which consists of a nationwide survey of the African American, Caribbean Black, and non-Hispanic White adult population, is based on a stratified, multi-stage area probability sample of the non-institutionalized civilian population in the 48 contiguous states [46-48]. 


\subsubsection{Recruitment of Adolescents}

The adolescent sample was drawn only from African American and Caribbean Black households. To recruit the adolescent sample, all African American and Caribbean Black households that included a participant in the NSAL-Adult survey were screened for eligible adolescents living in the household. Adolescents were then randomly selected from the provided list. When more than one eligible youth was living in the household, two adolescents were selected based on the gender of the 1st selected adolescent.

\subsubsection{NSAL-A Sample and Weight}

As a result of the above procedure, the NSAL-A sample was non-independent. In response, the NSAL-A data were weighted to adjust for non-independence in selection probabilities within the households, as well as clustering, strata, and non-response rates across households and individuals. Finally, the NSAL-A weighted data was post-stratified to represent the national estimates based on gender and age among Black youth [44,45].

Additional details regarding NSAL sampling have been published elsewhere [46-48]. While African Americans were sampled from large cities or other urban and rural areas, Caribbean Blacks were exclusively sampled from large cities.

\subsubsection{Analytical Sample in the Current Study}

Participants in the NSAL included 1170 ethnically diverse Black adolescents. The participants were African American $(n=810)$ or Caribbean Black $(n=360)$ youth who participated in the NSAL. The original adolescent sample consisted of 1193 cases, but 23 were dropped for analyses because they were 18 or older at the time of the interview. Thus, the resulting sample is 1170 African American $(n=810)$ and Caribbean Black $(n=360)$ youth ranging in age from 13 to 17 who were attached to the adult households (i.e., their parents participated in the NSAL study).

\subsection{Interview}

Approximately $82 \%$ of the data were collected via face-to-face home interviews. The remaining $18 \%$ of the data were conducted either entirely or partially by telephone interviews. Face-to-face interviews were computer-assisted personal interviews (CAPIs), a preferred interviewing technique when the survey instrument is long and complex. In CAPIs, interviewers use computers to input the respondents' answers to questions. Interviews lasted $100 \mathrm{~min}$ on average and all interviews were performed in the English language. The overall response rate was $80.6 \%$, with $80.4 \%$ for African Americans and $83.5 \%$ for Caribbean Blacks.

\subsection{Measures}

The study also collected demographic factors (i.e., age, gender, and ethnicity) as control variables. Obesity was measured using self-reports of height and weight and family support was also self-reported. All self-reported data were provided by youth themselves.

\subsubsection{Ethnicity}

Youth ethnicity was identified according to the ethnicity of the parents who were living in the same household at the time of the survey. Parents self-identified as African American if they were Black and did not have ancestral ties to the Caribbean. Parents identified as Caribbean Black if they were Black and from a country included on a list of Caribbean countries presented by the interviewers, or if their parents or grandparents were born in a Caribbean country. The thirteen Caribbean countries included were: (1) Cuba, (2) the Dominican Republic, (3) Haiti, (4) the Bahamas, (5) Jamaica, (6) Trinidad and Tobago, (7) Dominica, (8) Saint Lucia, (9) Antigua and Barbuda, (10) Barbados, (11) Saint Vincent and the Grenadines, (12) Grenada, and (13) Saint Kitts and Nevis. 


\subsubsection{Obesity}

NSAL-A collected data on Body Mass Index (BMI) based on adolescents' self-reported weights and heights. Although people tend to underestimate their weight and overestimate their height [49] which results in an underestimation of BMI [50], BMI based on self-reported weight and height has been shown to strongly correlate with BMI based on direct measures [51]. We used the standard definition of obesity in youth, which is based on the comparison of BMI with the 95th percentile BMI of the age- and gender- specific norms. We categorized our participants to obese (those with BMI \% equal or greater than 95th percentile) versus non-obese (those with BMI \% less than 95) individuals. Thus, obesity was treated as a dichotomous variable in this study $[52,53]$.

\subsubsection{Family Support}

The NSAL-A measured the amount of emotional and tangible support each adolescent received from the family using a 6-item survey. Items included How often do your family members (1) make you feel loved and cared for? (2) listen to you talk about your private problems and concerns? (3) express interest and concern in your wellbeing? (4) provide you with transportation? (5) help you financially? and (6) help you with child care or babysitting? If the answer was "Never", participants were asked "Was that because you never needed help?" Response categories were: Very Often (score 1), Fairly Often (score 2), Not Too Often (score 3), and Never (score 4). We coded as missing if the participant had not needed support. We calculated a total score ranging from 5 to 20, with higher scores indicating low family support [54,55]. (Cronbach's $\alpha=0.750)$.

\subsection{Statistical Analysis}

To account for the complex survey design of the NSAL-A, we weighted the data using Stata 13.0 (Stata Corp., College Station, TX, USA). We applied Taylor series approximation technique for estimation of complex design-based standard errors (SE). Percentages reported in this study are weighted to depict nationally representative figures. As in the NSAL-A, the Caribbean Black sample is more clustered than the African American sample, thus SEs are systematically larger for Caribbean Blacks than for African Americans. This results in more conservative findings for Caribbean Blacks.

In this study, we used survey logistic regression for multivariable analysis by considering obesity as the outcome, family support (high score indicating low support) as the main predictor, age as the control, and ethnicity and gender as moderators. We ran a number of models to determine the moderating role of gender, ethnicity, and their intersection on our outcome of interest. In the first step, we ran the model with the pooled sample, controlling for the main effects of ethnicity and gender. In the next step, we conducted the analysis by ethnicity, gender, or their intersection subsamples. Adjusted odds ratio (OR), SE, and 95\% confidence intervals were reported. $p$-Values less than 0.05 were considered statistically significant. We did not need to adjust $p$-value as we did not run multiple tests, but the same test in the pooled sample and subgroups.

\section{Results}

Participants were on average 15 years old $(\mathrm{SD}=1.42)$ and had the following age distribution: $13-14(n=477,40 \%), 15-16(n=441,41 \%)$ and $17(n=252,19 \%)$ years old. There were slightly more girls $(n=605,52 \%)$ than boys $(n=563,48 \%)$. Of the 1170 youth, $96 \%$ identified as a high school student. Family income ranged from US\$ $0-520$ thousand, with a median of US\$28,000. Caribbean Blacks had a higher median income (US\$32,250) compared to African Americans (US\$26,000) $(p<0.001)$.

Table 1 describes the sample distributions for gender, ethnicity, age, family support, and obesity in the pooled sample, and based on ethnicity and gender. 
Table 1. Descriptive statistics in the pooled sample and based on ethnicity and gender.

\begin{tabular}{|c|c|c|c|c|c|c|c|c|c|c|}
\hline & \multicolumn{6}{|c|}{ Gender } & \multicolumn{4}{|c|}{ Ethnicity } \\
\hline & & All & & Males & & Females & & African American & & Caribbean Blacks \\
\hline & $\%(\mathrm{SE})$ & $95 \% \mathrm{CI}$ & $\%(\mathrm{SE})$ & $95 \% \mathrm{CI}$ & $\%(\mathrm{SE})$ & $95 \% \mathrm{CI}$ & $\%(\mathrm{SE})$ & $95 \% \mathrm{CI}$ & $\%(\mathrm{SE})$ & $95 \% \mathrm{CI}$ \\
\hline \multicolumn{11}{|l|}{ Gender } \\
\hline Male & $50.02(0.02)$ & $46.49-53.54$ & & & & & $50.39(0.02)$ & $46.57-54.20$ & $44.78(0.02)$ & $39.98-49.68$ \\
\hline Female & $49.98(0.02)$ & $46.46-53.51$ & & & & & $49.61(0.02)$ & $45.80-53.43$ & $55.22(0.02)$ & $50.32-60.02$ \\
\hline \multicolumn{11}{|l|}{ Ethnicity } \\
\hline African Americans & $93.37(0.01)$ & $91.89-94.60$ & $94.07(0.01)$ & $92.69-95.20$ & $92.68(0.01)$ & $90.64-94.31$ & & & & \\
\hline Caribbean Blacks & $6.63(0.01)$ & $5.40-8.11$ & $5.93(0.01)$ & $4.80-7.31$ & $7.32(0.01)$ & $5.69-9.36$ & & & & \\
\hline \multicolumn{11}{|l|}{ Obesity } \\
\hline Non-Obese & $75.31(0.02)$ & $71.13-79.06$ & $75.92(0.03)$ & $70.51-80.62$ & $74.69(0.02)$ & $69.39-79.34$ & $75.08(0.02)$ & $70.62-79.06$ & $78.54(0.06)$ & $63.68-88.42$ \\
\hline Obese & $\begin{array}{c}24.69(0.02) \\
\text { m (SE) }\end{array}$ & $\begin{array}{c}20.94-28.87 \\
95 \% \text { CI }\end{array}$ & $\begin{array}{c}24.08(0.03) \\
\text { m (SE) }\end{array}$ & $\begin{array}{c}19.38-29.49 \\
95 \% \text { CI }\end{array}$ & $\begin{array}{c}25.31(0.02) \\
\mathrm{m}(\mathrm{SE})\end{array}$ & $\begin{array}{c}20.66-30.61 \\
95 \% \text { CI }\end{array}$ & $\begin{array}{c}24.92(0.02) \\
\mathrm{m}(\mathrm{SE})\end{array}$ & $\begin{array}{c}20.94-29.38 \\
95 \% \text { CI }\end{array}$ & $\begin{array}{c}21.46(0.06) \\
\text { m (SE) }\end{array}$ & $\begin{array}{c}11.58-36.32 \\
95 \% \text { CI }\end{array}$ \\
\hline Age & $14.98(0.06)$ & $14.86-15.10$ & $14.98(0.07)$ & $14.84-15.12$ & $14.98(0.09)$ & $14.80-15.15$ & $14.96(0.07)$ & $14.83-15.10$ & $15.22(0.06)$ & $15.09-15.35$ \\
\hline Family Support (Low) & $3.55(0.01)$ & $3.52-3.58$ & $3.55(0.02)$ & $3.51-3.59$ & $3.55(0.02)$ & $3.51-3.59$ & $3.55(0.02)$ & $3.52-3.58$ & $3.55(0.03)$ & $3.49-3.61$ \\
\hline
\end{tabular}

Data: National Survey of American Life-Adolescent Supplement (NSAL-A); Sample size: 1170 African American and Caribbean Black 13-17-year old youth. SE: Standard Error; CI:

Confidence Interval, m: mean. 
Table 2 summarizes five logistic regressions. Model 1 for the pooled sample showed that low family support was not associated with higher risk of obesity ( $\mathrm{OR}=1.35,95 \% \mathrm{CI}=0.96-1.89)$. Subsequently; Model 2 for African Americans; Model 3 for Caribbean Blacks; Model 4 for males; and Model 5 for females also showed no significant associations between low family support and risk of obesity.

Table 2. Logistic regression in the pooled sample and based on race and gender.

\begin{tabular}{lccc}
\hline & OR (SE) & 95\% CI & $p$ \\
\hline All & & & \\
Ethnicity (Caribbean Blacks) & $0.84(0.30)$ & $0.41-1.72$ & 0.628 \\
Gender (Female) & $1.07(0.17)$ & $0.77-1.48$ & 0.682 \\
Age & $0.92(0.06)$ & $0.81-1.04$ & 0.162 \\
Family Support (Low) & $1.35(0.22)$ & $0.96-1.89$ & 0.082 \\
Intercept & $0.38(0.45)$ & $0.04-4.09$ & 0.418 \\
\hline African Americans & & & \\
Gender (Female) & $1.09(0.19)$ & $0.77-1.54$ & 0.614 \\
Age & $0.91(0.06)$ & $0.80-1.04$ & 0.173 \\
Family Support (Low) & $1.39(0.23)$ & $0.98-1.96$ & 0.061 \\
Intercept & $0.35(0.43)$ & $0.03-4.34$ & 0.398 \\
\hline Caribbean Blacks & & & \\
Gender (Female) & $0.75(0.51)$ & $0.18-3.19$ & 0.675 \\
Age & $1.00(0.09)$ & $0.82-1.22$ & 0.990 \\
Family Support (Low) & $0.77(0.68)$ & $0.11-5.15$ & 0.768 \\
Intercept & $1.12(4.20)$ & $0.00-3554.5$ & 0.977 \\
\hline Males & & & \\
Ethnicity (Caribbean Blacks) & $0.99(0.16)$ & $0.72-1.37$ & 0.955 \\
Age & $0.85(0.06)$ & $0.74-0.99$ & 0.035 \\
Family Support (Low) & $1.23(0.27)$ & $0.79-1.90$ & 0.346 \\
Intercept & $1.59(2.20)$ & $0.10-26.15$ & 0.741 \\
\hline Females & & & \\
Ethnicity (Caribbean Blacks) & $0.69(0.44)$ & $0.19-2.51$ & 0.562 \\
Age & $0.99(0.10)$ & $0.81-1.20$ & 0.902 \\
Family Support (Low) & $1.53(0.33)$ & $0.99-2.36$ & 0.054 \\
Intercept & $0.09(0.15)$ & $0.00-2.44$ & 0.148 \\
\hline
\end{tabular}

Outcome: Obesity; Data: National Survey of American Life-Adolescent Supplement (NSAL-A); Sample size: 1170 African American and Caribbean Black 13-17 year old youth. OR: Odds Ratio.

Table 3 summarizes four additional models for ethnicity by gender groups. The association between low family support and risk of obesity was significant among African American females $(\mathrm{OR}=1.60,95 \% \mathrm{CI}=1.01-2.55)$. We did not find such an association for African American males $(\mathrm{OR}=1.26,95 \% \mathrm{CI}=0.82-1.92)$, Caribbean Black males $(\mathrm{OR}=0.68,95 \% \mathrm{CI}=0.01-54.85)$, and Caribbean Black females $(\mathrm{OR}=0.78,95 \% \mathrm{CI}=0.42-1.44)$.

Table 3. Logistic regression in the pooled sample and based on the intersection of race and gender.

\begin{tabular}{lccc}
\hline & OR (SE) & $\mathbf{9 5 \% ~ C I ~}$ & $p$ \\
\hline African American Male & & & \\
Age & $0.84(0.06)$ & $0.72-0.98$ & 0.032 \\
Family Support (Low) & $1.26(0.26)$ & $0.82-1.92$ & 0.275 \\
Intercept & $1.75(2.46)$ & $0.10-31.16$ & 0.692 \\
\hline Caribbean Black Male & & & \\
Age & $1.15(0.13)$ & $0.90-1.46$ & 0.251 \\
Family Support (Low) & $0.68(1.40)$ & $0.01-54.85$ & 0.855 \\
Intercept & $0.16(1.38)$ & $0.00-1.59$ & 0.835 \\
\hline
\end{tabular}


Table 3. Cont.

\begin{tabular}{lccc}
\hline & OR (SE) & $\mathbf{9 5 \% ~ C I ~}$ & $p$ \\
\hline African American Female & & & \\
Age & $0.99(0.10)$ & $0.81-1.22$ & 0.940 \\
Family Support (Low) & $1.60(0.37)$ & $1.01-2.55$ & 0.050 \\
Intercept & $0.07(0.12)$ & $0.00-2.37$ & 0.135 \\
\hline Caribbean Black Female & & & \\
Age & $0.90(0.08)$ & $0.74-1.10$ & 0.294 \\
Family Support (Low) & $0.78(0.22)$ & $0.42-1.44$ & 0.402 \\
Intercept & $2.76(5.77)$ & $0.03-243.44$ & 0.634
\end{tabular}

Outcome: Obesity; Data: National Survey of American Life-Adolescent Supplement (NSAL-A); Sample size: 1170 African American and Caribbean Black 13-17 year old youth.

\section{Discussion}

In a national sample of Black youth, this study documented the role of low family support on risk of obesity. This study also showed heterogeneity of this association based on the intersection of ethnicity and gender. Although low family support was a risk factor of obesity for African American females $(\mathrm{OR}=1.60)$, the association did not reach significance for young African American males, Caribbean Black males, or Caribbean Black females. For Caribbean Black males $(\mathrm{OR}=0.68)$ and Caribbean Black females $(\mathrm{OR}=0.78)$, although not significant, the direction of the association was reversed.

Our findings suggest that low family support may be a risk factor for obesity among African American females. Similar findings have been reported previously [2,19]. Jackson has attributed disproportionately high risk of obesity among African American women to the specific coping mechanisms that they use in dealing with stress [56]. African American women have a high tendency to turn to high calorie food in response to stress [57,58]. Future research is needed to understand how coping mechanisms mediate gender specific effects of stress on obesity among African Americans.

Only a handful of studies have tested the effect of general family processes on risk of obesity of offspring [2,35-38]. Only a small subset of these studies has enrolled Blacks or African Americans [2]. Based on our findings, in addition to family processes that are directly involved in eating, exercise, and life style, general family processes also influence risk of obesity. Youth who do not experience a positive family environment may be at an increased risk of obesity, as they may not benefit from the buffering effect of family support [59], particularly when they face stress and adversity on a daily basis.

In a recent longitudinal study of African American youth, low maternal support at baseline predicted an increase in BMI two decades later in females, but not males. The association remained significant net of socioeconomic status, family structure, and mental health (anxiety and depression). The study did not find any association between baseline paternal support and future obesity among African American males [2]. These findings fully support our results.

Based on our findings, the effect of low family support as a risk factor for obesity among Black youth varies based on the intersection of ethnicity and gender. Previous research has also shown that race, ethnicity, gender, and their intersections alter psychological correlates of obesity $[22,26,29,30]$. Differences in psychosocial determinants of obesity between African American males, African American females, Caribbean Black males, and Caribbean Black females have been previously reported $[17,20,28]$.

These findings are in support of the intersectionality approach [60-62]. Intersections of race, ethnicity, culture, and social class shape family processes such as parenting styles and behaviors [63-67]. Emotional attachment and supportive relations between family members are also influenced by values, cultures, life conditions, and environment. The effects of these family processes are also shaped by the intersections of race, ethnicity, culture, gender, and social class [68-75]. 
A stronger effect of low family support on obesity risk of African American females is in line with the literature that shows that the gender of the offspring is a vulnerability factor to the effects of socioenvironmental and family characteristics [18,74]. Overall, parents are generally more affectionate with girls than boys [75,76]. Girls receive more emotional support from their parents compared to boys [77]. African American families are not an exception to this rule [67]. Boys and girls are also differently under influence of parenting and family environment [78-82]. This may explain why poor family relations may have a larger effect on obesity for African American females than males [83,84]. More studies have focused on the effect of family function on obesity of adults $[16,85]$ or children [86,87] rather than youth [2]. In a study that used data from the Danish Twin Registry, comparison of same-sexed twin pairs discordant for BMI showed that perceived parental antipathy and neglect predict obesity [16]. Parenting support received from mothers and fathers also have differential effects on the mental health of male and female African American youth $[18,74,88]$.

Our findings have implications for public policy and public health practice. Interventions such as Fathers and Sons $[89,90]$ and Strong African American Families [91,92] are culturally sensitive, accepted by the community, and effective. Public policies should enhance opportunities to support positive family functioning specifically in the lives of African American women, which may reduce their obesity rates.

Our findings are relevant as obesity is an epidemic among African American women. In 2011, compared to Non-Hispanic Whites, African American women were $80 \%$ more likely to be obese, with four out of each five African American women being either overweight or obese [93]. Obesity increases the risk of a wide range of cardiovascular outcomes [94,95], while years lived with obesity increases the risk of death from cardiovascular causes, independent of BMI [95]. Obesity is also an established risk factor for hypertension [96], diabetes [97,98], cardiovascular disease [99], and stroke [100].

Although this study focused on low family support as a risk factor, our findings do not blame the victim. Family is a core value in Black culture [101,102]. Financial, economic, historical, and societal and political reasons have shifted their family structures from a more traditional nuclear form to an adaptable extended type. Adaptive family roles have been also taken by the family members. In addition to family, African American and Black families endorse a high sense of resilience. Along with other resilience factors such as racial identity, religiosity, and social networks, family support should be incorporated into interventions to improve health disparities [103-105]. Caldwell et al., provide a framework to enhance family support of Black families [74].

Family support can be enhanced on a large scale. There are policies and programs that effectively enhance supportive relations and the engagement of parents in the family $[74,89,90,106]$. Thus, family function should be considered as a target of national and local interventions; such investments have the capacity to also prevent obesity among African American women. Other researchers have also previously suggested that enhancing family and parental affection may be an effective strategy to prevent obesity [36]. More investment should be made on evidence-based family programs that enable families to have supportive relations in majority Black communities $[74,89,90]$. Examples of policy solutions are those which reduce parental stress and provide incentives for family engagement in the life of African American families. Such policies that enhance the family environment of African Americans will have health promoting effects on their offspring. Economic, financial, and employment policies are all particularly important, as most African American families struggle economically and live in socially disadvantaged neighborhoods.

To conclude, low family support does not have a universal role as a risk factor for obesity in all sub-groups of Black youth, with a more salient role for African American females than for African American males, Caribbean Black males, and Caribbean Black females.

Acknowledgments: The NSAL is mostly supported by the National Institute of Mental Health, with grant U01-MH57716 to James S. Jackson. Other support came from the Office of Behavioral and Social Science Research at the National Institutes of Health and the University of Michigan. Cleopatra Caldwell is the principle investigator of the NSAL-A. Shervin Assari is partially funded by the Heinz C. Prechter Bipolar Research Fund as well as the Richard Tam Foundation at the University of Michigan Depression Center. 
Author Contributions: C.H.C. was the principle investigator of the NSAL-A, and contributed to the design of the mother study. S.A. designed and conducted this analysis and drafted the manuscript. C.H.C. revised the manuscript. Both authors approved the final draft.

Conflicts of Interest: The authors declare no conflict of interest.

\section{References}

1. Berge, J.M. A review of familial correlates of child and adolescent obesity: What has the 21st century taught us so far? Int. J. Adolesc. Med. Health 2009, 21, 457-483. [CrossRef] [PubMed]

2. Assari, S.; Caldwell, C.H.; Zimmerman, M.A. Low parental support in late adolescence predicts obesity in young adulthood; Gender differences in a 12-year cohort of African Americans. J. Diabetes Metab. Disord. 2015, 14, 47. [CrossRef] [PubMed]

3. Johnson, S.L.; Hughes, S.O.; Cui, X.; Li, X.; Allison, D.B.; Liu, Y.; Goodell, L.S.; Nicklas, T.; Power, T.G.; Vollrath, K. Portion sizes for children are predicted by parental characteristics and the amounts parents serve themselves. Am. J. Clin. Nutr. 2014, 99, 763-770. [CrossRef] [PubMed]

4. Frankel, L.A.; O'Connor, T.M.; Chen, T.; Nicklas, T.; Power, T.G.; Hughes, S.O. Parents' perceptions of preschool children's ability to regulate eating: Feeding style differences. Appetite 2014, 76, 166-174. [CrossRef] [PubMed]

5. Sleddens, E.F.C.; O'Connor, T.M.; Watson, K.B.; Hughes, S.O.; Power, T.G.; Thijs, C.V.; de Vries, N.K.; Kremers, S.P.J. Development of the Comprehensive General Parenting Questionnaire for caregivers of 5-13 year olds. Int. J. Behav. Nutr. Phys. Act. 2014, 11, 15. [CrossRef] [PubMed]

6. Power, T.G.; Sleddens, E.F.C.; Berge, J.; Connell, L.; Govig, B.; Hennessy, E.; Liggett, L.; Mallan, K.; Santa Maria, D.; Odoms-Young, A.; et al. Contemporary research on parenting: Conceptual, methodological, and translational issues. Child. Obes. 2013, 9, S87-S94. [CrossRef] [PubMed]

7. Papaioannou, M.A.; Cross, M.B.; Power, T.G.; Liu, Y.; Qu, H.; Shewchuk, R.M.; Hughes, S.O. Feeding style differences in food parenting practices associated with fruit and vegetable intake in children from low-income families. J. Nutr. Educ. Behav. 2013, 45, 643-651. [CrossRef] [PubMed]

8. Garstein, M.A.; Young, B.N.; Bridgett, D.; Panksepp, J.; Power, T.G. Origins of effortful control: Infant and parent contributions. Infancy 2013, 18, 149-183. [CrossRef] [PubMed]

9. Morrison, H.; Power, T.G.; Nicklas, T.; Hughes, S.O. Exploring the effects of maternal eating patterns on maternal feeding and child eating. Appetite 2013, 63, 77-83. [CrossRef] [PubMed]

10. Schmitz, K.H.; Lytle, L.A.; Phillips, G.A.; Murray, D.M.; Birnbaum, A.S.; Kubik, M.Y. Psychosocial correlates of physical activity and sedentary leisure habits in young adolescents: The Teens Eating for Energy and Nutrition at School Study. Prev. Med. 2002, 34, 266-278. [CrossRef] [PubMed]

11. Kremers, S.; Brug, J.; de Vries, H.; Engels, R. Parenting style and adolescent fruit consumption. Appetite 2003, 41, 43-50. [CrossRef]

12. Hughes, S.O.; Patrick, H.; Power, T.G.; Fisher, J.O.; Anderson, C.B.; Nicklas, T.A. The impact of child care providers' feeding on children's food consumption. J. Dev. Behav. Pediatr. 2007, 28, 100-107. [CrossRef] [PubMed]

13. Hughes, S.O.; Power, T.G.; Fisher, J.O.; Mueller, S.; Nicklas, T.A. Revisiting a neglected construct: Parenting styles in a child-feeding context. Appetite 2005, 44, 83-92. [CrossRef] [PubMed]

14. Gorin, A.A.; Crane, M.M. The obesogenic environment. In Handbook of Childhood and Adolescent Obesity; Jelalian, E., Steele, R., Eds.; Springer: New York, NY, USA, 2008; pp. 145-162.

15. Burke, V.; Beilin, L.J.; Dunbar, D. Family lifestyle and parental body mass index as predictors of body mass index in Australian children: A longitudinal study. Int. J. Obes. Relat. Metab. Disord. 2001, 25, 147-157. [CrossRef] [PubMed]

16. Vámosi, M.E.; Heitmann, B.L.; Thinggaard, M.; Kyvik, K.O. Parental care in childhood and obesity in adulthood: A study among twins. Obesity (Silver Spring) 2011, 19, 1445-1450. [CrossRef] [PubMed]

17. Assari, S.; Caldwell, C.H. Gender and Ethnic Differences in the Association Between Obesity and Depression Among Black Adolescents. J. Racial Ethn. Health Disparities 2015, 2, 481-493. [CrossRef] [PubMed]

18. Wang, D.; Li, Y.; Lee, S.G.; Wang, L.; Fan, J.; Zhang, G.; Wu, J.; Ji, Y.; Li, S. Ethnic differences in body composition and obesity related risk factors: Study in Chinese and white males living in China. PLoS ONE 2011, 6, e19835. [CrossRef] [PubMed] 
19. Assari, S.; Moghani Lankarani, M.; Caldwell, C.H.; Zimmerman, M.A. Fear of Neighborhood Violence During Adolescence Predicts Development of Obesity a Decade Later: Gender Differences among African Americans. Arch. Trauma Res. 2016, 5, e31475. [CrossRef] [PubMed]

20. Blostein, F.; Assari, S.; Caldwell, C.H. Gender and Ethnic Differences in the Association between Body Image Dissatisfaction and Binge Eating Disorder among Blacks. J. Racial Ethn. Health Disparities 2016. [CrossRef] [PubMed]

21. Assari, S.; Caldwell, C.H.; Zimmerman, M.A. Perceived Neighborhood Safety During Adolescence Predicts Subsequent Deterioration of Subjective Health Two Decades Later; Gender Differences in a Racially-Diverse Sample. Int. J. Prev. Med. 2015, 6, 117. [CrossRef] [PubMed]

22. Carter, J.D.; Assari, S. Sustained Obesity and Depressive Symptoms over 6 Years: Race by Gender Differences in the Health and Retirement Study. Front. Aging Neurosci. 2017, 8, 312. [CrossRef] [PubMed]

23. Assari, S. Psychosocial Correlates of Body Mass Index in the United States: Intersection of Race, Gender and Age. Iran. J. Psychiatry Behav. Sci. 2016, 10, e3458. [CrossRef] [PubMed]

24. Assari, S.; Nikahd, A.; Malekahmadi, M.R.; Lankarani, M.M.; Zamanian, H. Race by Gender Group Differences in the Protective Effects of Socioeconomic Factors Against Sustained Health Problems Across Five Domains. J. Racial Ethn. Health Disparities 2016. [CrossRef] [PubMed]

25. Assari, S.; Lankarani, M.M. The Association Between Obesity and Weight Loss Intention Weaker Among Blacks and Men than Whites and Women. J. Racial Ethn. Health Disparities 2015, 2, 414-420. [CrossRef] [PubMed]

26. Assari, S. The link between mental health and obesity: Role of individual and contextual factors. Int. J. Prev. Med. 2014, 5, 247-249. [PubMed]

27. Assari, S. Additive Effects of Anxiety and Depression on Body Mass Index among Blacks: Role of Ethnicity and Gender. Int. Cardiovasc. Res. J. 2014, 8, 44-51. [PubMed]

28. Assari, S. Association between obesity and depression among American Blacks: Role of ethnicity and gender. J. Racial Ethn. Health Disparities 2014, 1, 36-44. [CrossRef]

29. Hicken, M.T.; Lee, H.; Mezuk, B.; Kershaw, K.N.; Rafferty, J.; Jackson, J.S. Racial and ethnic differences in the association between obesity and depression in women. J. Womens Health 2013, 22, 445-452. [CrossRef] [PubMed]

30. Lagarrigue, A.; Ajana, S.; Capuron, L.; Féart, C.; Moisan, M.P. Obesity in French Inmates: Gender Differences and Relationship with Mood, Eating Behavior and Physical Activity. PLoS ONE 2017, 12, e0170413. [CrossRef] [PubMed]

31. Barry, D.; Petry, N.M. Associations between body mass index and substance use disorders differ by gender: Results from the National Epidemiologic Survey on Alcohol and Related Conditions. Addict Behav. 2009, 34, 51-60. [CrossRef] [PubMed]

32. Barry, D.; Pietrzak, R.H.; Petry, N.M. Gender differences in associations between body mass index and DSM-IV mood and anxiety disorders: Results from the National Epidemiologic Survey on Alcohol and Related Conditions. Ann. Epidemiol. 2008, 18, 458-466. [CrossRef] [PubMed]

33. Barry, D.; Petry, N. Gender differences in associations between stressful life events and body mass index. Prev. Med. 2008, 47, 498-503. [CrossRef] [PubMed]

34. Hughes, S.O.; Shewchuk, R.M.; Baskin, M.L.; Nicklas, T.A.; Qu, H. Indulgent feeding style and children's weight status in preschool. J. Dev. Behav. Pediatr. 2008, 29, 403-410. [CrossRef] [PubMed]

35. Olvera, N.; Power, T.G. Parenting styles and overweight in Mexican-American children: A longitudinal Study. J. Pediatr. Psychol. 2010, 35, 243-249. [CrossRef] [PubMed]

36. Barnett, D.S.T.; Paradis, G.M.D.; Kakinami, I. American Heart Association Meeting. 2014. American Heart Association Meeting Report Abstract MP34. Available online: http://newsroom.heart.org/news/rulingwith-an-iron-fist-could-make-your-child-pack-on-pounds\#item531e01d2ee750e3c1900074e (accessed on 30 January 2017).

37. Power, T.G. Parenting dimensions and styles: A brief history and recommendations for future research. Child. Obes. 2013, 9, S14-S21. [CrossRef] [PubMed]

38. Hughes, S.; O'Connor, T.; Power, T. Parenting and children's eating patterns: Examining parental control in a broader context. Int. J. Child. Adolesc. Health 2008, 1, 323-330.

39. Lissau, I.; Sørensen, T.I. Parental neglect during childhood and increased risk of obesity in young adulthood. Lancet 1994, 343, 324-327. [CrossRef] 
40. Lee, H.; Harris, K.M.; Lee, J. Multiple levels of social disadvantage and links to obesity in adolescence and young adulthood. J. Sch. Health 2013, 83, 139-149. [CrossRef] [PubMed]

41. Cohen, S.; Wills, T.A. Stress, social support, and the buffering hypothesis. Psychol. Bull. 1985, 98, 310-357. [CrossRef] [PubMed]

42. Assari, S. Race and Ethnicity, Religion Involvement, Church-based Social Support and Subjective Health in United States: A Case of Moderated Mediation. Int. J. Prev. Med. 2013, 4, 208-217. [PubMed]

43. Assari, S.; Watkins, D.C.; Caldwell, C.H. Race Attribution Modifies the Association Between Daily Discrimination and Major Depressive Disorder Among Blacks: The Role of Gender and Ethnicity. J. Racial Ethn. Health Disparities 2015, 2, 200-210. [CrossRef] [PubMed]

44. Seaton, E.K.; Caldwell, C.H.; Sellers, R.M.; Jackson, J.S. An intersectional approach for understanding perceived discrimination and psychological well-being among African American and Caribbean Black youth. Dev. Psychol. 2010, 46, 1372-1379. [CrossRef] [PubMed]

45. Seaton, E.K.; Caldwell, C.H.; Sellers, R.M.; Jackson, J.S. Developmental characteristics of African American and Caribbean Black adolescents' attributions regarding discrimination. J. Res. Adolesc. 2010, 20, 774-788. [CrossRef] [PubMed]

46. Jackson, J.S.; Torres, M.; Caldwell, C.H.; Neighbors, H.W.; Nesse, R.M.; Taylor, R.J. The National Survey of American Life: A study of racial, ethnic, and cultural influences on mental disorders and mental health. Int. J. Methods Psychiatr. Res. 2004, 13, 196-207. [CrossRef] [PubMed]

47. Jackson, J.S.; Neighbors, H.W.; Nesse, R.M.; Trierweiler, S.J.; Torres, M. Methodological innovations in the National Survey of American Life. Int. J. Methods Psychiatr. Res. 2004, 13, 289-298. [CrossRef] [PubMed]

48. Heeringa, S.; Wagner, J.; Torres, M.; Duan, N.; Adams, T.; Berglund, P. Sample designs and sampling methods for the Collaborative Psychiatric Epidemiology Studies (CPES). Int. J. Methods Psychiatr. Res. 2004, 13, 221-239. [CrossRef] [PubMed]

49. Taylor, A.W.; Dal Grande, E.; Gill, T.K.; Chittleborough, C.R.; Wilson, D.H.; Adams, R.J. How valid are self-reported height and weight? A comparison between CATI self-report and clinic measurements using a large cohort study. Aust. N. Z. J. Public Health 2006, 30, 238-246. [CrossRef] [PubMed]

50. Simon, G.E.; Von Korff, M.; Saunders, K.; Miglioretti, D.L.; Crane, P.K.; van Belle, G. Association between obesity and psychiatric disorders in the US adult population. Arch. Gen. Psychiatry 2006, 63, 824-830. [CrossRef] [PubMed]

51. Gavin, A.R.; Rue, T.; Takeuchi, D. Racial/ethnic differences in the association between obesity and major depression disorder: Findings from the Comprehensive Psychiatric Epidemiology Surveys. Public Health Rep. 2010, 125, 698-708. [CrossRef] [PubMed]

52. Lang, I.A.; Kipping, R.R.; Jago, R.; Lawlor, D.A. Variation in childhood and adolescent obesity prevalence defined by international and country-specific criteria in England and the United States. Eur. J. Clin. Nutr. 2011, 65, 143-150. [CrossRef] [PubMed]

53. Dumith, S.C.; FariasJúnior, J.C. Overweight and obesity in children and adolescents: Comparison of three classification criteria based on body mass index. Rev. Panam. Salud Publica 2010, 28, 30-35. [CrossRef] [PubMed]

54. Taylor, R.J.; Forsythe-Brown, I.; Taylor, H.O.; Chatters, L.M. Patterns of Emotional Social Support and Negative Interactions among African American and Black Caribbean Extended Families. J. Afr. Am. Stud. 2014, 18, 147-163. [CrossRef] [PubMed]

55. Chatters, L.M.; Taylor, R.J.; Woodward, A.T.; Nicklett, E.J. Social support from church and family members and depressive symptoms among older African Americans. Am. J. Geriatr. Psychiatry 2015, 23, 559-567. [CrossRef] [PubMed]

56. Jackson, J.S.; Knight, K.M.; Rafferty, J.A. Race and unhealthy behaviors: Chronic stress, the HPA axis, and physical and mental health disparities over the life course. Am. J. Public Health 2010, 100, 933-939. [CrossRef] [PubMed]

57. Mezuk, B.; Abdou, C.M.; Hudson, D.; Kershaw, K.N.; Rafferty, J.A.; Lee, H.; Jackson, J.S. “White Box" Epidemiology and the Social Neuroscience of Health Behaviors: The Environmental Affordances Model. Soc. Ment. Health 2013, 3. [CrossRef] [PubMed]

58. Thomas, J.L.; Stewart, D.W.; Lynam, I.M.; Daley, C.M.; Befort, C.; Scherber, R.M.; Mercurio, A.E.; Okuyemi, K.S.; Ahluwalia, J.S. Support needs of overweight African American women for weight loss. Am. J. Health Behav. 2009, 33, 339-352. [CrossRef] [PubMed] 
59. Parsons, T.J.; Power, C.; Logan, S.; Summerbell, C.D. Childhood predictors of adult obesity: A systematic review. Int. J. Obes. Relat. Metab. Disord. 1999, 23 (Suppl. 8), S1-S107. [PubMed]

60. Bauer, G.R. Incorporating intersectionality theory into population health research methodology: Challenges and the potential to advance health equity. Soc. Sci. Med. 2014, 110, 10-17. [CrossRef] [PubMed]

61. Else-Quest, N.M.; Hyde, J.S. Intersectionality in quantitative psychological research: II. Methods and techniques. Psychol. Women Q. 2016, 40, 319-336. [CrossRef]

62. Abichahine, H.; Veenstra, G. Inter-categorical intersectionality and leisure-based physical activity in Canada. Health Promot. Int. 2016. [CrossRef] [PubMed]

63. MacPhee, D.; Fritz, J.; Miller-Heyl, J. Ethnic variations in personal social networks and parenting. Child. Dev. 1996, 67, 3278-3295. [CrossRef]

64. Knight, G.P.; Virdin, L.M.; Roosa, M. Socialization and family correlates of mental health outcomes among Hispanic and Anglo American children: Consideration of cross-ethnic scalar equivalence. Child. Dev. 1994, 65, 212-224. [CrossRef] [PubMed]

65. Mogro-Wilson, C. The influence of parental warmth and control on Latino adolescent alcohol use. Hisp. J. Behav. Sci. 2008, 30, 89-105. [CrossRef]

66. Ipsa, J.M.; Fine, M.A.; Halgunseth, L.C.; Harper, S.; Robinson, J.; Boyce, L.; Brooks-Gunn, J.; Brady-Smith, C. Maternal intrusiveness, maternal warmth, and mother-toddler relationship outcomes: Variations across low-income ethnic and acculturation groups. Child. Dev. 2004, 75, 1613-1631.

67. Longest, K.C.; Taylor, L.C.; Barnett, M.A.; Raver, C.C. Parenting Styles African American and White Families with Young Children: Findings from an Observational Study. Presented at the annual meeting of the American Sociological Association, TBA, New York, NY, USA, August 2007.

68. Pinderhughes, E.E.; Dodge, K.A.; Bates, J.E.; Pettit, G.S.; Zelli, A. Discipline responses: Influences of parent's socioeconomic status, ethnicity, beliefs about parenting, stress, and cognitive-emotional processes. J. Fam. Psychol. 2000, 14, 380-400. [CrossRef] [PubMed]

69. Gonzales, N.A.; Hiraga, Y.; Cauce, A.M. Observing mother-daughter interaction in African-American and Asian American families. In Resiliency in African-American Families; McCubbin, H.I., Thompson, E.A., Thompson, A.I., Futrell, J.A., Eds.; Sage: Thousand Oaks, CA, USA, 1998; pp. 259-286.

70. Varela, R.E.; Vernberg, E.M.; Sanchez-Sosa, J.J.; Riveros, A.; Mitchell, M.; Mashunkashey, J. Parenting style of Mexican, Mexican American, and Caucasian-Non-Hispanic families: Social context and cultural influences. J. Fam. Psychol. 2004, 18, 651-657. [CrossRef] [PubMed]

71. Cardona, P.G.; Nicholson, B.C.; Fox, R.A. Parenting among Hispanic and Anglo-American mothers with young children. J. Soc. Psychol. 2000, 140, 357-365. [CrossRef] [PubMed]

72. Hill, N.E.; Bush, K.R.; Roosa, M.W. Parenting and family socialization strategies and children's mental health: Low-income Mexican-American and Euro-American mothers and children. Child. Dev. 2003, 74, 189-204. [CrossRef] [PubMed]

73. Chao, R.; Kanatsu, A. Beyond socioeconomics: Explaining ethnic group differences in parenting through cultural and immigration processes. Appl. Dev. Sci. 2008, 12, 181-187. [CrossRef]

74. Caldwell, C.H.; Allen, J.O.; Assari, S. Family influences on African American Men's Health: Family-based interventions. In Boys and Men in African American Families; Springer: Cham, Swaziland, 2016; pp. 195-214.

75. Biblarz, T.J.; Stacey, J. How Does the Gender of Parents Matter? J. Marriage Fam. 2010, 72, 3-22. [CrossRef]

76. Dornbusch, S.M.; Ritter, P.L.; Leiderman, P.H.; Roberts, D.F.; Fraleigh, M.J. The relation of parenting style to adolescent school performance. Child. Dev. 1987, 58, 1244-1257. [CrossRef] [PubMed]

77. Cassano, M.; Perry-Parrish, C.; Zeman, J. Influence of gender on parental socialization of children's sadness regulation. Soc. Dev. 2007, 16, 210-231. [CrossRef]

78. Khooshabi, K.; Ameneh-Forouzan, S.; Ghassabian, A.; Assari, S. Is there a gender difference in associates of adolescents' lifetime illicit drug use in Tehran, Iran? Arch. Med. Sci. 2010, 6, 399-406. [CrossRef] [PubMed]

79. Baheiraei, A.; Soltani, F.; Ebadi, A.; Cheraghi, M.A.; Rahimi Foroushani, A. Family and peer risk factors as predictors of lifetime tobacco use among Iranian adolescents: Gender similarities and differences. Glob. J. Health Sci. 2014, 6, 63-75. [CrossRef] [PubMed]

80. Denton, R.E.; Kampfe, C.M. The relationship between family variables and adolescent substance abuse: A literature review. Adolescence 1994, 29, 475-495. [PubMed] 
81. Silveri, M.M.; Tzilos, G.K.; Pimentel, P.J.; Yurgelun-Todd, D.A. Trajectories of adolescent emotional and cognitive development: Effects of sex and risk for drug use. Ann. N. Y. Acad. Sci. 2004, 1021, 363-370. [CrossRef] [PubMed]

82. McArdle, P.; Wiegersma, A.; Gilvarry, E. European adolescent substance use: The roles of family structure. Funct. Gend. 2007, 97, 329-336.

83. McLoyd, V.C. The impact of economic hardship on Black families and children: Psychological distress, parenting, and socioemotional development. Child. Dev. 1990, 61, 311-346. [CrossRef] [PubMed]

84. Derogatis, L.R.; Spencer, P.M. The Brief. Symptom Inventory (BSI): Administration, Scoring and Procedures Manual_I. Baltimore; National Computer Systems: Riyadh, Saudi Arabia, 1993.

85. Thomas, C.; Hyppönen, E.; Power, C. Obesity and type 2 diabetes risk in midadult life: The role of childhood adversity. Pediatrics 2008, 121, e1240-e1249. [CrossRef] [PubMed]

86. Birch, L.L.; Fisher, J.O. Mothers' child-feeding practices influence daughters' eating and weight. Am. J. Clin. Nutr. 2000, 71, 1054-1061. [PubMed]

87. Cutting, T.M.; Fisher, J.O.; Grimm-Thomas, K.; Birch, L.L. Like mother, like daughter: Familial patterns of overweight are mediated by mothers' dietary disinhibition. Am. J. Clin. Nutr. 1999, 69, 608-613. [CrossRef] [PubMed]

88. Assari, S.; Smith, J.R.; Caldwell, C.H.; Zimmerman, M.A. Gender differences in longitudinal links between neighborhood fear, parental support, and depression among African American emerging adults. Societies 2015, 5, 151. [CrossRef]

89. Caldwell, C.H.; Wright, J.C.; Zimmerman, M.A.; Walsemann, K.M.; Williams, D.; Isichei, P.A. Enhancing adolescent health behaviors through strengthening non-resident father-son relationships: A model for intervention with African-American families. Health Educ. Res. 2004, 19, 644-656. [CrossRef] [PubMed]

90. Caldwell, C.H.; Rafferty, J.; Reischl, T.M.; De Loney, E.H.; Brooks, C.L. Enhancing parenting skills among nonresident African American fathers as a strategy for preventing youth risky behaviors. Am. J. Community Psychol. 2010, 45, 17-35. [CrossRef] [PubMed]

91. Brody, G.H.; Murry, V.M.; Gerrard, M.; Gibbons, F.X.; McNair, L.; Brown, A.C.; Wills, T.A.; Molgaard, V.; Spoth, R.L.; Luo, Z.; et al. The strong African American families program: Prevention of youths' high-risk behavior and a test of a model of change. J. Fam. Psychol. 2006, 20, 1-11. [CrossRef] [PubMed]

92. Brody, G.H.; Murry, V.M.; Gerrard, M.; Gibbons, F.X.; Molgaard, V.; McNair, L.; Brown, A.C.; Wills, T.A.; Spoth, R.L.; Luo, Z.; et al. The Strong African American Families Program: Translating research into prevention programming. Child. Dev. 2004, 75, 900-917. [CrossRef] [PubMed]

93. National Center for Health Statistics. Health, United States, 2012: With Special Feature on Emergency Care; Library of Congress Catalog Number 76-641496 For sale by Superintendent of Documents; U.S. Government Printing Office: Washington, DC, USA, 2013.

94. Klein, S.; Burke, L.E.; Bray, G.A.; Blair, S.; Allison, D.B.; Pi-Sunyer, X.; Hong, Y.; Eckel, R.H.; American Heart Association Council on Nutrition, Physical Activity, and Metabolism. Clinical implications of obesity with specific focus on cardiovascular disease: A statement for professionals from the American Heart Association Council on Nutrition, Physical Activity, and Metabolism: Endorsed by the American College of Cardiology Foundation. Circulation 2004, 110, 2952-2967. [PubMed]

95. Reis, J.P.; Loria, C.M.; Lewis, C.E.; Powell-Wiley, T.M.; Wei, G.S.; Carr, J.J.; Terry, J.G.; Liu, K. Association between duration of overall and abdominal obesity beginning in young adulthood and coronary artery calcification in middle age. JAMA 2013, 310, 280-288. [CrossRef] [PubMed]

96. Landsberg, L.; Aronne, L.J.; Beilin, L.J.; Burke, V.; Igel, L.I.; Lloyd-Jones, D.; Sowers, J. Obesity-related hypertension: Pathogenesis, cardiovascular risk, and treatment: A position paper of The Obesity Society and the American Society of Hypertension. J. Clin. Hypertens. (Greenwich) 2013, 15, 14-33. [CrossRef] [PubMed]

97. Mokdad, A.H.; Ford, E.S.; Bowman, B.A.; Dietz, W.H.; Vinicor, F.; Bales, V.S.; Marks, J.S. Prevalence of obesity, diabetes, and obesity-related health risk factors, 2001. JAMA 2003, 289, 76-79. [CrossRef] [PubMed]

98. Ruland, S.; Hung, E.; Richardson, D.; Misra, S.; Gorelick, P.B. African American Antiplatelet Stroke Prevention Study Investigators. Impact of obesity and the metabolic syndrome on risk factors in African American stroke survivors: A report from the AAASPS. Arch. Neurol. 2005, 62, 386-390. [CrossRef] [PubMed]

99. Antillon, D.; Towfighi, A. No time to 'weight': The link between obesity and stroke in women. Womens Health (Lond. Engl.) 2011, 7, 453-463. [CrossRef] [PubMed] 
100. Kurth, T.; Gaziano, J.M.; Berger, K.; Kase, C.S.; Rexrode, K.M.; Cook, N.R.; Buring, J.E.; Manson, J.E. Body mass index and the risk of stroke in men. Arch. Intern. Med. 2002, 162, 2557-2562. [CrossRef] [PubMed]

101. McAdoo, H.P. Black Families; Sage: Thousand Oaks, CA, USA, 2007.

102. Sudarkasa, N. Interpreting the African Heritage in Afro-American Family Organization. Families in the US: Kinship and Domestic Politics; Temple University Press: Philadelphia, PA, USA, 1998; pp. 91-104.

103. Morgan, S.; McDaniel, A.; Miller, A.T.; Preston, S.H. Racial differences in household and family structure at the turn of the century. Am. J. Soc. 1993, 799-828. [CrossRef]

104. Margaret, S. Black Families: Interdisciplinary Perspectives, 2nd ed.; Cheatham, H.E., Stewart, J.B., Eds.; Transaction Publishers: New Brunswick, NJ, Canada, 1990; pp. 124-125.

105. Dixon, P. Marriage among African Americans: What does the research reveal? J. Afr. Am. Stud. 2009, 13, 29-46. [CrossRef]

106. Howard Caldwell, C.; Antonakos, C.L.; Assari, S.; Kruger, D.; de Loney, E.H.; Njai, R. Pathways to prevention: Improving nonresident African American fathers' parenting skills and behaviors to reduce sons' aggression. Child. Dev. 2014, 85, 308-325. [CrossRef] [PubMed]

(C) 2017 by the authors. Licensee MDPI, Basel, Switzerland. This article is an open access article distributed under the terms and conditions of the Creative Commons Attribution (CC BY) license (http:/ / creativecommons.org/licenses/by/4.0/). 